\title{
Allergic diseases of the skin and drug allergies - 2020. The association between DRESS and the diminished numbers of peripheral $B$ lymphocytes and natural killer cells
}

\author{
Mehtap Yazicioglư ${ }^{1 *}$, Reyhan Elmas ${ }^{2}$, Burhan Turgut ${ }^{3}$, Tugba Genchellac ${ }^{2}$ \\ From 2nd WAO International Scientific Conference (WISC 2012) \\ Hyderabad, India. 6-9 December 2012
}

\section{Background}

Drug reaction with eosinophilia and systemic symptoms (DRESS) is a drug-induced,severe multiorgan system reaction whose exact pathogenesis remains unknown. This study aimed at evaluating specific changes in peripheral blood lymphocyte subtypes associated with DRESS during antibiotic treatment.

\section{Methods}

We analyzed six patients with DRESS. A complete blood count and peripheral blood lymphocytes immunophenotyping were carried out at symptom onset and at followup visits. Acute-phase reactants and liver enzymes were measured in all patients. Other tests - viral serology, serum immunoglobulin levels, and skin tests were performed when possible.

\section{Results}

B-cell counts were low in all patients at the onset of DRESS, and natural killer (NK) cells were low in all cases exceptone. During recovery, B-cell numbers were within a normal range in five patients. In one, there was even a 10fold increase in B-cell counts, although the level was mildly low after 3 months. NK-cell numbers were within a normal range in three patients. The mean numbers of $\mathrm{B}$ cells and NK cells were significantly higher in the second samples compared to the values on admission. Serum IgA and IgM levels were low in one patient. The drug provocation test was positive with cefotaxime in one patient. Viral serology, performed on five patients, was negative.

${ }^{1}$ Pediatrics and Pediatric Allergy, Trakya University, Edirne, Turkey

Full list of author information is available at the end of the article

\section{Conclusions}

A decrease in B-cell and NK-cell counts was the most consistent finding associated with the onset of antibioticinduced DRESS in our patients. This immunologic alteration might be a useful predictor of DRESS development.

\section{Author details}

'Pediatrics and Pediatric Allergy, Trakya University, Edirne, Turkey. ${ }^{2}$ Pediatrics, Trakya University, Edirne, Turkey. ${ }^{3}$ Internal Medicine, Trakya University, Edirne, Turkey.

\section{Published: 23 April 2013}

\section{doi:10.1186/1939-4551-6-S1-P107}

Cite this article as: Yazicioglu et al:: Allergic diseases of the skin and drug allergies - 2020. The association between DRESS and the diminished numbers of peripheral $B$ lymphocytes and natural killer cells. World Allergy Organization Journal 2013 6(Suppl 1):P107.

Submit your next manuscript to BioMed Central and take full advantage of:

- Convenient online submission

- Thorough peer review

- No space constraints or color figure charges

- Immediate publication on acceptance

- Inclusion in PubMed, CAS, Scopus and Google Scholar

- Research which is freely available for redistribution 